Vol. 18 (2009): 191-205.

\title{
Review article \\ Legumes in Finnish agriculture: history, present status and future prospects
}

Frederick L. Stoddard ${ }^{1 *}$, Simo Hovinen ${ }^{2}$, Markku Kontturi ${ }^{3}$, Kristina Lindström ${ }^{4}$ and Arja Nykänen ${ }^{5}$

${ }^{1}$ Department of Applied Biology, PO Box 27, FI-00014 University of Helsinki, Finland

${ }^{2}$ Formerly Boreal Plant Breeding, now retired

${ }^{3}$ MTT Agrifood Research Finland, Plant Production Research, FI-31600 Jokioinen, Finland

${ }^{4}$ Department of Applied Chemistry and Microbiology, PO Box 56,

FI-00014 University of Helsinki, Finland

${ }^{5}$ MTT Agrifood Research Finland, Plant Production Research, Lönnrotinkatu 3, FI-50100 Mikkeli, Finland

*email: frederick.stoddard@helsinki.fi

Legumes are important in world agriculture, providing biologically fixed nitrogen, breaking cereal disease cycles and contributing locally grown food and feed, including forage. Pea and faba bean were grown by early farmers in Finland, with remains dated to 500 BC. Landraces of pea and faba bean were gradually replaced by better adapted, higher quality materials for food use. While grain legumes have been restricted by their long growing seasons to the south of the country, red, white and alsike clovers are native throughout and have long been used in leys for grazing, hay and silage. Breeding programmes released many cultivars of these crops during the 1900s, particularly pea and red clover. A.I. Virtanen earned the 1945 Nobel Prize in Chemistry for his work on both nitrogen fixation and silage preservation. Use of crop mixtures may appear modern, but farmers used them already in the early 1800 s, when oat was used to support pea, and much effort has been devoted to improving the system and establishing its other benefits.

Although international cultivars have been easily accessible since Finland's 1995 entry into the European Union, the combination of feed quality and appropriate earliness is still needed, as $<1 \%$ of arable land is sown to grain legumes and an increase to $9-10 \%$ would allow replacement of imported protein feeds. Climate change will alter the stresses on legume crops, and investment in agronomy, physiology and breeding is needed so that farmers can gain from the many advantages of a legume-supported rotation.

Key-words: red clover, pea, faba bean, crop rotation, nitrogen fixation 


\section{Introduction}

Legumes are an integral element of sustainable agricultural systems around the world. In symbiosis with rhizobium bacteria in root nodules, they provide biologically fixed nitrogen $(\mathrm{N})$, so not only are they free of the need for $\mathrm{N}$ fertilizer, they also contribute to the $\mathrm{N}$ nutrition of the following crop. A grass-free legume crop breaks soil-borne cereal disease cycles while legume root exudates enhance the growth of many beneficial soil organisms. Grain and forage legumes can be locally grown to provide stockfeed rich in protein, energy and bioactive compounds, without the need for long-distance shipment. Grain legumes provide protein-rich food for people who by preference or necessity do not eat meat. Legumes add to the options available to the farmer, improving farm viability; they increase regional biodiversity and landscape diversity, and they support pollinating bee populations. In spite of these benefits and in the context of agricultural intensification, the cultivation of legume crops has gone through a long decline in Europe (FAOstat 2009), leading to a dependence on protein imports. Finland is no exception to this trend. In 2008, less than $0.5 \%$ of Finland's nearly 2.3 million ha of arable land was sown to grain legumes (FAOstat 2009, Niemi and Ahlstedt 2008). About $25 \%$ of the arable land is forage, silage or hay crops (Niemi and Ahlstedt 2008) and only part of this is sown to legume or grass-legume blends. Crop production is limited by the shortness of the growing season, averaging 170 days of which the frost-free interval is 120 days, or about 1300 growing degree days above $5{ }^{\circ} \mathrm{C}$, in the southernmost part of the country, decreasing northwards (Finnish Meteorological Institute 2009).

In this review, we examine the history of legume cultivation in Finland, its current status, and the prospects for making better use of this valuable group of crops.

\section{Prehistory and history to 1900}

Pea (Pisum sativum L.) and faba bean (Vicia faba L.) were grown in Sweden during the Stone Age. Peas were spread further in Scandinavia by monks and oldest information about pea cultivation is from the 12th century (Grotenfelt 1922). The Finnish word herne, meaning pea, has a Baltic origin, indicating that pea cultivation arrived from the south (Huurre 2003). Pollen analysis shows that peas were grown in Niuskala, near Turku, about 500 BC. Archaeological findings of faba bean are younger than those of pea and the cultivation of faba beans was less common, but beans were grown in Laitila and Hattula around AD 600-800 (Huurre 2003). The shape of a dent in a piece of clay pot found in Vammala suggests that lentil (Lens culinaris Medik.) was also known (Huurre 2003). Faba bean probably arrived from the East, as the word papu, meaning bean, has common roots with the Slavic bob. In the 1500 s most faba bean cultivation was in the eastern part of the country (Elfving 1896).

In Finland, pea cultivation has been documented since the 17 th century and in the next century it was common in the southwest, where soils contained enough clay and arable fields were available, and spread slowly throughout the country (Grotenfelt 1922). The limited arable area restricted pea cultivation in the east and north of country, and the need for a long growing season restricted it in the north (Soininen 1974). By 1800 pea cultivation had reached the Oulu river valley (Soininen 1974). Jacob Tengström, Bishop of Turku, wrote in 1803 that growing peas in northern parts of country was seldom successful due to the short summer and early night frosts that damage the crop prematurely (Grotenfelt 1922). Similarly, faba bean cultivation was well documented in the south and west (Wilmi 2003) to which it was considered to be restricted by its relatively long growing season and soil preferences (Soininen 1974).

In Sweden, peas were grown in royal estates through the country, although on less than $1 \%$ of the arable land. The royal estates in Finland also grew peas (Vilkuna 2003). In 1533 the royal estate in Kokemäki sowed 4.5 spann (1 Stockholm spann 
Vol. 18 (2009): 191-205.

was a volume of $47 \mathrm{~L}$ ) of peas, covering $3 \%$ of the total sown area. In the royal estates of Savolax, peas and faba beans were less than $1 \%$ of the plantings (Vilkuna 2003). In the castle of Hämeenlinna the share of these grain legumes in the middle of 16 th century was about $6 \%$, indicating an intensive cultivation of legumes. The cultivated faba bean was known as hevospapu, horse bean, in addition to härkäpapu, ox bean. It was known for its suitability for soils with a higher clay content than suited peas, but it also ripened later (Elfving 1896). Talonpoikaispapu, peasant bean, was a name also applied to some faba beans in Karelia (Soininen 1974) and emphasizes its distinction from the pea grown on royal estates.

In Eastern Finland, pea was regarded as an arable crop, and therefore not suited for growing on land cleared by slash-and-burn (kaski in Finnish). Furthermore, the fields in the east of Finland were often located on hilltops and slopes with light moraine soil that was less suitable for peas (Soininen 1974). The Finnish natural scientist Pehr Adrian Gadd, working in the second half of the 1700s, commented that the peas widely grown in the country were "grey peas" with small seeds and late ripening. He was of the opinion that alternative types should be found, as the grey peas germinated later than white peas and yielded less. Nevertheless, Gadd noted that grey peas had one advantage, that their stems were softer and more suitable as cattle feed. This suggests to the modern reader that the grey pea would have lodged readily.

Accurate information of bean cultivation is available starting from the 18th century when faba beans were grown in counties of Uusimaa, Satakunta, Häme and Savo, but not in Karelia (Grotenfelt 1922). In the 19th century bean cultivation was more common in southern parts of Savo and Karelia, although to a limited extent.

During the 1700 s the grey pea was progressively replaced in Sweden by common white and green peas, although cultivation was first limited to the estates owned by gentry. The plants were taller, their seed was bigger, the yield was higher and they ripened earlier, but they required more fertile soil than grey pea. By the early 1800 s, white and green pea types replaced grey pea in Finland as well. At the same time it became common practice to sow pea with oat (Avena sativa L.), i.e., intercropping (Soininen 1974). Intercropping meant large savings in labour, as the need to provide sticks to support pea plants in the field was avoided. As a field crop, pea was first in economic importance after cereals, although the yields were poorer. Towards the end of the 19th century pea was included in the yield and trade statistics of cereals, but data on cultivation area and yields of pea are limited. In 1878, when the first data for the whole of Finland is available, the volume of pea seed sown was only $1.5 \%$ of the volume of cereal seed sown (Soininen 1974). At the beginning of the 1900s, small areas of faba bean were grown in Southwest Finland, in South Savo and on a few farms in Karelia.

Because faba bean has always been a minor crop, its agronomy has remained relatively undeveloped in this country, and information about old cultivation methods is scarce (Grotenfelt 1922). During the 18th century, beans and peas were sown about the same time. Often bean fields were situated near a village next to farm houses and were very small, so-called moisio or kodismaa. Faba bean was known as the crop that was last to ripen in the autumn. In 19th century faba beans were sown either broadcast or in rows. In case of row cultivation, the sower walked after the plough, $s a$ $h r a$, and dropped the seeds one by one into the every second or third furrow (Grotenfelt 1922). Sparse seeding in bean was regarded as very important because weed control was very difficult and quite often unsuccessful. Faba bean and pea were harvested and threshed by the same methods. Peas and faba beans brought important nutrition into the human diet, and the stems were used to feed cattle (Vilkuna 2003).

Unlike pea and faba bean, red (Trifolium pratense L.), alsike (T. hybridum L.) and white ( $T$. repens $\mathrm{L}$.) clovers are among the native plants of Finland and are successfully cultivated in the northern parts of Finland beyond $67^{\circ} \mathrm{N}$. Cultivation of red clover in Finland was noted at the end of 19th century (Grotenfelt 1922, Valle 1929). It was the basis of protein production in Finnish leys and was included in almost all leys until the 1960s (Paatela 1953, Raatikainen and Raatikainen 1975). 


\section{Stoddard F.L. et al. Legumes in Finnish agriculture}

Red clover and alsike clover were mixed with timothy (Phleum pratense L.) to form hay or pasture grassland (Sauli 1916). Valle (1935) pointed out that red clover was the most important species in grasslands for hay making, because it fixes $\mathrm{N}$, which timothy cannot do.

\section{Developments up to 1945}

The estate owner Constantin Boije was the pioneer of plant breeding in Finland. He bred pure lines from local crop landraces which resulted in the first Finnish varieties 'Ilola' oat and 'Nord' pea at the beginning of the 1900s. The farmers central co-operative Hankkija established a plant breeding station and experimental farm in Hattula parish in 1913. Pea breeding was included in its work from the beginning. An important target was to breed round green peas for use in pea soup but in addition to this other targets were to breed marrowfat (processing) types, sugar peas and feed peas. Single plant selection from local landraces was the first step in order to get pure lines and then crosses were made to increase variation (Sauli 1916). Breeding was conducted in Hattula for only a few years until Hankkija bought a new farm, Tammisto, in 1913 and breeding work was moved there (Sauli 1921).

Field pea and garden or vining pea were the only grain legumes in the breeding programme in Tammisto. Rainy weather conditions often hampered pea growing in Finland, so stem stiffness against lodging, earliness and high seed yield were the most important breeding objectives for field peas, and high quality and taste for garden peas (Sauli 1925). The first marketed varieties were single plant selections from local landraces or foreign varieties and included marrowfats, sugar peas, dry peas and feed peas at the beginning of pea breeding in Finland, but subsequently only dry peas for food or feed have been bred in the country.

A plant breeding department was established in the Agricultural Research Centre of Finland in 1926 and was transferred from Tikkurila to Jokioinen in 1928. Pea breeding was included in its programme from the beginning in a significant extent (Pesola 1948). This produced an agreement between Hankkija and the Agricultural Research Centre (ARC) whereby pea breeding was closed at the Hankkija Plant Breeding Institute (Valle 1938). Altogether, 8 varieties from Hankkija and 6 varieties from ARC were released onto the market before 1939, and in addition there were many local varieties on the seed market.

Sauli (1916) noticed that progenies from single plants from red clover and alsike clover showed wide variation in winter hardiness. Red clover breeding in Tammisto was initiated by gathering promising local landraces into plot trials with foreign, mainly Northern varieties as standards. The hardiest and best yielding accessions were selected for continuation. They were cultivated for many years in isolation until only the hardiest plants were still living and finally seeds were harvested and formed the basic seed for a possible new cultivar. The same method was applied to alsike clover breeding (Valle 1938). 'Tammisto' red clover (Table 1) was the first Finnish cultivar, selected from a local landrace from Tuulos parish and released in 1937. White clover was considered very important for pasture grasslands and its breeding produced promising cultivars 'Tammisto 1' and 'Tammisto 2', but seed production proved to be too difficult in the Finnish climate so no cultivars were marketed (Valle 1938).

Two important names in Finnish history conducted agronomic research in this interval. Lauri Kristian Relander, who later became the country's second president, demonstrated that pea yields were greater, with earlier ripening and higher harvest index, from sowing in early May than from sowing two weeks later, and that slightly higher sowing rates $\left(220 \mathrm{~kg} \mathrm{ha}^{-1}\right.$ instead of $\left.180 \mathrm{~kg} \mathrm{ha}^{-1}\right)$ were preferable (Relander 1916). Artturi Ilmari Virtanen developed the AIV-System, a N self-sufficient cultivation method, that included crop rotation with pastures, cereal grains and intensive red clover leys for winter-feeding preserved as silage. Silage was made by a new method using mineral acids for preservation, by which silage is still made in northern conditions. Virtanen was awarded the Nobel Prize for Chemistry in 1945 for "his research 
Vol. 18 (2009): 191-205.

and inventions in agricultural and nutrition chemistry, especially for his fodder preservation method". Virtanen was also known for his research on biological $\mathrm{N}$ fixation and intercropping of oat and pea (Virtanen 1933, Karström and Virtanen 1937, Virtanen 1946).

\section{From 1945 to joining the EU}

Pea breeding was continued by the state at Jokoinen during the war years (Pesola 1942). The main breeding objectives were earliness, lodging resistance and high yield. Cooking quality became increasingly important: soup peas should be green, round, easily softened in cooking, with a traditional flavour. Yellow-seeded pea cultivars did not achieve popularity (Pesola 1948). Some selection work from old landraces was continued in Tammisto and a green-seeded cultivar 'Kalle' (Table 1) was released onto the market in 1952 by Hankkija (Kivi 1955), remaining the most popular cultivar for many years. Pea breeding was resumed by Hankkija and the focus was on clearly short-stemmed varieties in order to improve lodging resistance. The short-stem trait was obtained from Dutch cultivars (Kivi 1975). The wholesale firm Kesko founded an educational and experimental farm Hahkiala in Hauho parish in 1963 and established co-operation with the Svalöf-Weibull plant breeding company of Sweden, leading to the introduction of many highly valued field crop cultivars, including pea, onto the Finnish market.

Table 1. Some important legume cultivars released by Finnish breeders

\begin{tabular}{|c|c|c|c|}
\hline Species & Cultivar & Year of release & Significance \\
\hline pea & Nord & 1904 & first Finnish cultivar, wide cultivation \\
\hline pea & Martta & 1934 & green seeded, wide and long cultivation \\
\hline pea & Sinikka & 1939 & green, high quality, wide and long cultivation \\
\hline pea & Kalle & 1952 & green, leading cultivar for decades \\
\hline pea & Riitto & 1961 & green with high quality, wide cultivation \\
\hline pea & Kiri & 1972 & early ripening, green, wide cultivation \\
\hline pea & Hertta & 1975 & green, very high quality, wide cultivation \\
\hline pea & Hankkijan Tammi & 1984 & first afila-pea, green, popular cross parent \\
\hline pea & Helka & 1986 & afila-pea for export, marketed in many countries \\
\hline pea & Pika & 1986 & afila-pea, very early, wide and long cultivation \\
\hline pea & Sohvi & 1992 & short stemmed, popular in ecological cultivation \\
\hline pea & Tiina & 1993 & early, green, wide cultivation for food \\
\hline pea & Sunna & 1995 & extremely early, yellow, for northern conditions \\
\hline faba bean & Hankkijan Ukko & 1984 & first beige-seeded bean, early, high protein yield \\
\hline faba bean & Kontu & 1997 & beige-seeded, early, very high protein yield \\
\hline red clover & Tammisto & 1937 & first bred Finnish cultivar, leading cultivar for decades \\
\hline alsike clover & Tammisto & 1948 & first bred Finnish cultivar, for moist soils \\
\hline red clover & Jokioinen & 1976 & high winter hardiness, for more Northern areas \\
\hline red clover & Tepa & 1976 & first Finnish tetraploid, high yield and overwintering \\
\hline red clover & Venla & 1976 & high yield and high protein yield, long cultivation \\
\hline
\end{tabular}




\section{Stoddard F.L. et al. Legumes in Finnish agriculture}

Breeding of faba bean was based on local foodquality landraces that were collected in Karelia by Kivi during the late 1960s as the cultivation of the crop had nearly ended (Hovinen and Kivi 1975). Although faba bean is a late crop, the Karelian landraces offered excellent sources of earliness. Crossbreeding was started by Hankkija at Anttila Experimental Station where Hankkija's Plant Breeding Institute was based. Foreign cultivars were also used as parents in order to broaden the genetic base. The main breeding objectives were to combine earliness with an acceptable yield level and to ensure effective biological $\mathrm{N}$ fixation. Three cultivars, Mikko, Ukko and Kontu, were released (Table 1) (Hovinen 1982, 1984, 1990).

In the late $1960 \mathrm{~s}$, pea germplasm was obtained from the gene bank of the Vavilov Institute, Leningrad to be used in crosses by Hankkija, and was grown in observation plots in the field. One of the lines showed an unusual phenotype, with strong tendrils instead of leaflets (afila). Some crosses were done with it and many plants among segregating progenies expressed the same character. The material was, however, late in maturity. Some lines that were semi-long stemmed and expressed this afaf-genotype were selected for continuation in trials and used as parents in great number of pea crosses during the following years. Later on, foreign varieties with same leaf characteristics and enlarged stipules $(S t S t)$ were acquired for crosses. Between 1979 and 1986, some 300 pea crosses were made at Anttila. Breeding objectives were still lodging resistance and high seed yielding capacity. Breeding new cultivars with high and stable levels of protein for variable northern conditions is a difficult task, and instead, when breeding for better protein productivity it is much more effective to improve seed yield and yield stability than protein content (Karjalainen and Kortet 1987). Peas were considered as a domestic protein crop, which meant that a new cultivar also had to express high $\mathrm{N}$ fixation capacity, so high protein yields and high seed protein contents were possible (Hovinen 1988). The programme produced 9 varieties of semi-leafless (afaf StSt) peas on market, some of which were only for export.
Pea breeding at Jokioinen also produced many successful varieties between 1961 and 1992 (Multamäki and Kaseva 1987). Many of them were rather tall but produced good yields of the desired food quality, while short-stemmed and semi-leafless cultivars were also released (Saastamoinen 1992, 1995).

Tall peas were suitable for mixed cropping with oat, as was common practice. Intercropping of tall pea and oat was studied in Satakunta experimental station at Peipohja in 1935-1939 and 1945-1949 with the aim of increasing domestic protein production, preventing lodging of peas and improving yield stability (Virri 1939, Virri 1951). The intercrop of stiff-strawed cereals with peas prevented much of the lodging, made harvest easier and improved both yield and quality of the pea crop. The optimal sowing ratio of peas and cereal was between $3: 1$ and 4:1, depending on the growth conditions. The value of the residual biologically fixed nitrogen after the pea crop was estimated to equal 300-400 kg KNO $\mathrm{ha}^{-1}$ (Virri 1951), or 42-55 kg $\mathrm{N} \mathrm{ha}^{-1}$. The beneficial effect of peas on the growth of subsequent cereal crops was seen even in the third year.

In 1979 The Academy of Finland launched a research programme aiming at the reintroduction of biological $\mathrm{N}$ fixation into Finnish agriculture. Many of the results were published only in Finnish (Varis and Sundman 1983), especially those aiming at inoculant development. Commercially available inoculants for faba bean were compared in a field experiment at Viikki Experimental Farm in 1980 (Table 2). There were large differences between the plots, caused by seed variability but also by differences in effectiveness of the symbiosis. The Pelinoc preparation (Nitragen Company) for faba bean gave the best plant yield in comparison with Pelinoc for pea, the Swedish inoculant (Baljväxtlaboratoriet) and the Finnish Valio. Acetylene reduction measurements, which estimate nitrogenase activity, indicated that an especially high rate of $\mathrm{N}$ fixation at flowering was an indication of good yield, whereas high nitrogenase activity at pod filling was negatively correlated with yield. Thus, a well functioning symbiotic $\mathrm{N}$ fixation helps faba bean to adapt to the short growing season. These 
Vol. 18 (2009): 191-205.

experiments were followed by a strain collection effort that yielded a set of Finnish isolates that is still in use in Finnish inoculant manufacture.

Red clover rhizobia were similarly collected, tested and selected in laboratory, greenhouse and field experiments at different sites. The resulting core collection was characterized by good competitive ability and a capacity to form a harmonious symbiosis with the host plants (Lindström 1984a). Inoculation is advisable for forage legumes when the field has never before been sown to that species, and on soils affected by acidity factors (Lindström et al. 1985, Lindström and Myllyniemi 1987).

Breeding of red clover continued at Tammisto after the war years. Plot trials compared 100 local accessions from Finland and other Northern countries and none exceeded cv. 'Tammisto' in yield, though 'Ultuna' from Sweden matched it. Clover rot (Sclerotinia trifoliorum Erikss.) caused severe winter damage, especially in foreign accessions (Heikinheimo 1946). Ravantti (1960) stated that after testing of 48 foreign and 134 Finnish local red clovers, none of them was superior to 'Tammisto' red clover. In Finland, the only red clover grown is the late type, as the early is not sufficiently winter hardy for our conditions. The tetraploid red clover cv. 'Ulva' from Svalöf gave better yield than 'Tammisto' in first- to third- year leys and was recognized as having the greatest winter hardiness among late red clovers. Further breeding of red clover in Finland focussed on diploids, however, because seed production from tetraploids proved to be too uncertain (Nissinen and Raininko 1975). While 'Tammisto' remained the most important cultivar in cultivation, cv. 'Jokioinen' expressed even better winter hardiness and 'Venla' gave higher yields. Cv. 'Tepa', from Jokioinen, was the first tetraploid red clover from Finland. Mass selection, paired crosses, bulk and polycross breeding methods were applied to red clover breeding during the 1970s (Laitinen 1980). Subsequently, however, cultivation of leys for silage and dry hay was based on heavy use of $\mathrm{N}$ fertilizer, reducing the suitability and performance of red clover. Cultivation of red clover became restricted and demand for seed was low, but breeding of red clover continued (Kajaste 1990).

The first Finnish alsike clover cultivar, also called 'Tammisto' (Table 1), was selected from a Danish landrace that was grown in Finland under natural selection by hard winters and was released in 1948 (Heikinheimo 1950). Between 1933 and 1956, 26 foreign and 9 indigenous white clover varieties were tested at Tammisto. The foreign varieties, of forma hollandium, gave better yields than the Finnish, which represent f. sylvestre, although the winter hardiness of the Finnish material was superior to that of the foreign. Lucerne (Medica-

Table 2. Nitrogenase activity and yields of faba bean inoculated with four different commercial preparations compared with $\mathrm{N}$ fertilizer $\left(120 \mathrm{~kg} \mathrm{~N} \mathrm{ha}^{-1}\right)$ and uninoculated controls in a field experiment at Viikki Experimental Farm in 1980.

\begin{tabular}{lcccc}
\hline Treatment & \multicolumn{2}{c}{$\begin{array}{c}\text { Acetylene reduction activity } \\
\left(\mu \mathrm{mol} \mathrm{h}^{-1}\right)^{*}\end{array}$} & $\begin{array}{c}\text { Dry matter yields } \\
\left(\mathrm{kg} \mathrm{ha}^{-1}\right)^{\#)}\end{array}$ & $\begin{array}{c}\text { Nitrogen yields } \\
\left(\mathrm{kg} \mathrm{ha}^{-1}\right)^{\#)}\end{array}$ \\
\cline { 2 - 4 } & Flowering (16 July) & Pod filling (7 August) & \\
\hline Valio & $19.8 \pm 3.8^{\mathrm{bc})}$ & $11.4 \pm 2.9$ & $740 \pm 171$ & $37.5 \pm 8.8$ \\
Baljväxtaboratoriet & $12.2 \pm 2.8^{\mathrm{abc})}$ & $16.6 \pm 4.0$ & $480 \pm 133$ & $22.5 \pm 5.4$ \\
Pelinoc, pea & $11.3 \pm 1.8^{\mathrm{ab})}$ & $12.8 \pm 5.3$ & $582 \pm 141$ & $28.1 \pm 5.8$ \\
Pelinoc, faba bean & $30.0 \pm 7.0^{\mathrm{c})}$ & $13.6 \pm 3.3$ & $1062 \pm 423$ & $51.0 \pm 17.1$ \\
N fertilizer & $9.5 \pm 4.9^{\mathrm{ab})}$ & $11.4 \pm 4.4$ & $706 \pm 135$ & $34.8 \pm 6.5$ \\
Uninoculated & $6.8 \pm 1.6^{\mathrm{a})}$ & $7.7 \pm 1.4$ & $783 \pm 207$ & $38.4 \pm 10.1$ \\
\hline
\end{tabular}

\footnotetext{
${ }^{*}$ Mean \pm SE. Results per cylinder (diameter $10 \mathrm{~cm}$ ), N=6. See Lindström $1984 \mathrm{~b}$ for methodology.

\#) Mean \pm SE. $N=4$.

abc) Figures followed by the same letter were not statistically significant at $p<0.05$.
} 


\section{Stoddard F.L. et al. Legumes in Finnish agriculture}

go sativa L.) was cultivated in Finland on only a small scale (Ravantti 1965) owing to its uncertain winter hardiness, with lossed due to both frost and pathogenic fungi (Sclerotinia trifoliorum, Typhula sp.). The hardiest varieties were Swedish cultivars 'Alfa' and 'Tuna' as well as the first Finnish-selected lucerne 'Jokioinen'.

\section{Current status}

In the present context of increasing prices of fossil fuel and fertilizer, concerns about greenhouse gases and leaching of agricultural $\mathrm{N}$, and dependence on increasingly expensive, imported vegetable protein for animal feeding, legumes are receiving renewed interest from growers and researchers. Biological $\mathrm{N}$ fixation from the legume-rhizobium symbiosis is especially critical in organic farms where synthetic $\mathrm{N}$ fertilizer is not used. Appropriate cultivars of grain legumes can be used for feeding ruminants, monogastric livestock, poultry and fish, while the use of forage legumes in leys removes the need for application of large quantities of synthetic $\mathrm{N}$ fertilizer and improves both forage quality and end-product quality (Hides and Humphries 2000).

The common variety list inside the European Union means that seed lots of EU-listed cultivars grown in Finland can be certified, and many foreign cereal varieties are now marketed in Finland. The legume seed market is relatively unattractive because it is small and in many cases, farmers can retain seed. At present, the most effective imported legume cultivars are from Sweden and Estonia.

In temperate Europe, white clover is the most important perennial forage legume, followed by lucerne and red clover. In the boreal climate of Finland, red clover remains the most widely used perennial forage legume, but other species are also grown and improvements have been made through breeding in many countries, so it is worth examining the options. Lucerne and yellow-flowered lucerne (Medicago sativa ssp. falcata (L.) Arcang.) as well as goat's rue or fodder galega (Galega orientalis Lam.) can produce good yields in our condi- tions (Varis 1986), but they are used rarely in ley production. Modern cultivars of white clover were found to be well adapted to pasture use in Eastern parts of Finland (Kuusela 2004). The forage legumes are generally grown in mixtures with grasses including timothy, meadow fescue (Festuca pratensis L.) and tall fescue (Festuca arundinacea L.). Leys with legumes are harvested for silage twice in a growing season and a programme is available on the Internet for farmers to plan the right time for the first cut.

Common vetch (Vicia sativa L.) and hairy vetch (Vicia villosa Roth.) as well as pea and faba bean are used for whole crop silage as mixtures with spring cereals (oat, wheat (Triticum aestivum L. emend Thell.) and barley (Hordeum vulgare L.)) (Pursiainen and Tuori 2008). Well constructed mixtures, such as a 1:1 mixture of oat and faba bean, are more productive and present less of a risk of yield failure than monocultures (Helenius and Jokinen 1994). Mixtures also utilize N from the soil better than monocultures and $\mathrm{N}$ leaching is lower, because grasses utilize soil $\mathrm{N}$ effectively and thereby force the legumes to rely on biologically fixed N (Loges et al. 2000, Halling et al. 2002). In addition to their uses as forage, clovers and vetches are used in organic crop rotations for green manuring in Finland. Grass-clover leys leave up to $145 \mathrm{~kg}$ $\mathrm{N} \mathrm{ha}^{-1}$ in roots and stubble while pure legume crops can leave over $200 \mathrm{~kg} \mathrm{~N}^{-1}$ (Table 3). Estimates of total biological $\mathrm{N}$ fixation range widely within and between red clover - grass leys (Table 4).

The 'late' red clover type is further divided into two main groups: the tall, relatively late-flowering clover of southern Finland and the low, earlier flowering type of northern Finland. Intermediates also exist. The northern type is well adapted to the long snow cover (Ravantti 1961). The yield potential of red clover is high, but persistence is a problem, with many authors reporting a yield decrease in the third or sometimes already in the second year of production (Salonen and Hiivola 1963, Mela et al. 1980, Huokuna et al. 1985, Nykänen et al. 2000, Mela 2003, Nykänen et al. 2008a). This is mainly attributable to poor over-wintering and the effects of diseases such as clover rot and root rots (Fusarium spp.) (Ylimäki 1967, 1969). Mineral N ferti- 
Vol. 18 (2009): 191-205.

Table 3. Residual nitrogen effects of legumes in Finnish agricultural research

\begin{tabular}{|c|c|c|c|}
\hline System & Residual N, kg ha'-1 & Other effects & Reference \\
\hline Red clover - grass ley & $15-40$ & $\begin{array}{l}\text { Following cereal crop yielded } 28 \% \\
\text { more than after timothy ley }\end{array}$ & Teittinen et al. 1965 \\
\hline $\begin{array}{l}\text { Persian clover } \\
(\text { T. resupinatum L.) }\end{array}$ & 190 above ground & Cereal yields about $3.0 \mathrm{t} \mathrm{ha}^{-1}$ & $\begin{array}{l}\text { Poutala and Hannukkala } \\
1995\end{array}$ \\
\hline Hairy vetch & $\begin{array}{l}220 \text { above ground, } \\
4-7 \text { below ground }\end{array}$ & & $\begin{array}{l}\text { Poutala and Hannukkala } \\
1995\end{array}$ \\
\hline Red clover & $\begin{array}{l}20-160 \text { above ground } \\
4-135 \text { below ground }\end{array}$ & & Känkänen et al. 1998 \\
\hline Hairy vetch & $\begin{array}{l}40-240 \text { above ground, } \\
4-30 \text { below ground }\end{array}$ & & Känkänen et al. 1998 \\
\hline Red clover - grass ley & $\begin{array}{l}79-145 \text { in roots and } \\
\text { stubble }\end{array}$ & $\begin{array}{l}\text { No difference in following cereal } \\
\text { yields from continuous cereal }\end{array}$ & Nykänen et al. 2008b \\
\hline
\end{tabular}

Table 4. Estimates of biological nitrogen fixation from red clover - grass leys in Finland

\begin{tabular}{lll}
\hline System & Biological N fixation, $\mathrm{kg} \mathrm{ha}^{-1}$ & Reference \\
\hline Conventional management & $50-130$ & Varis and Sundman 1983 \\
Comparison of conventional and organic management & $90-115$ in organic plots & Väisänen 2000 \\
& 11 on conventional farms & \\
& 49 on organic farms & Nykänen 2008 \\
1-, 2- and 3-year-old organic leys & $40-150$ & Nykänen et al. 2008a \\
Variation within organic fields & $20-250$ in field 1 & \\
\hline
\end{tabular}

lization and high levels of inorganic $\mathrm{N}$ in the soil also decrease clover content and growth, because grasses out-compete the clovers in the presence of plenty of N (Haynes 1980, Spatz and Benz 2001). The choice of clover and grass species planted also influences the competition (Hakala and Jauhiainen 2007). As a result of either the last cut being too late or the winter being long, the content of water-soluble carbohydrates in the roots diminishes, reducing potential for recovery in the spring (Virtanen and Nurmia 1936, Pitkänen and Huokuna 1985). Red clover is sensitive to soil compaction and tap root injuries caused by heavy machinery, so modern cultivation methods can introduce their own drawbacks.

In comparison to grass forages, red clover forages result in higher nutritive values and greater intake by ruminants, leading to higher milk production (Heikkilä et al. 1992, Bertilsson et al. 2001, Vanhatalo et al. 2006) with higher polyunsaturated fatty acid concentration (Steinshamn et al. 2007, Vanhatalo et al. 2007, Steinshamn and Thuen 2008) and better animal performance in beef production (Lee et al. 2006). Red clover also has high yields of digestible organic matter, metabolizable energy and N (Dewhurst et al. 2001, Halling et al. 2002, Abberton and Marshall 2005). Clovers are richer in calcium, magnesium and many trace elements than grasses (Leaver 1985, Nykänen-Kurki and Hakkola 1994, Kuusela 2006) and legumes take up phosphorus, sulphur and potassium in relatively large amounts (Mulder et al. 1977, Marschner 1995). The decrease of organic matter digestibility in late summer is slower for clovers than for grasses, which gives a larger window of time for optimal harvesting of mixtures, as well (Rinne and Nykänen 2000). In some circumstances, however, clovers can cause bloating (Howarth 1975, Leaver 1985) and some contain phyto-oestrogens that can cause infertility problems although clear cases have 
Stoddard F.L. et al. Legumes in Finnish agriculture

not been proven in Finland (Kallela 1974, Mustonen et al. 2006).

The bulk of the grain legume crop remains food-grade dry pea. Faba bean, feed-grade pea, blue lupin (Lupinus angustifolius L.) and vetch are produced on very limited scales. Total grain legume areas declined in Finland from the late 1930s to the late 1960s (Fig. 1), as they did elsewhere in Europe as the continent moved from horse-based to tractor-based agriculture and living standards improved, allowing greater consumption of meat products. There was a clear resurgence of grower interest in the 1970s and again in the 1990s after introduction of semi-leafless pea in 1991, but areas are again relatively small in 2008 . The effects of improved cultivars and agronomic methods on yield per hectare are clear up to 1975 (Fig. 2) and thereafter the year-to-year variation is large. Examination of mean May-September temperature and rainfall data allows explanation of some of the high and low yield values. The two coldest growing seasons, 1962 and 1987 , were both $1.9^{\circ} \mathrm{C}$ cooler than the 1960-2007 average of $13.1{ }^{\circ} \mathrm{C}$, and the third coldest in 1977 was $1.2{ }^{\circ} \mathrm{C}$ lower. Furthermore, the two wettest seasons were 1987 and 2004, with $127 \mathrm{~mm}$ more rain than the long-term average of $303 \mathrm{~mm}$, while the third was 1962 with $83 \mathrm{~mm}$ more than the average. The 1999 season was the driest in the dataset, $156 \mathrm{~mm}$ less than average, but in other dry years such as 2006 (128 mm less rain), 1976 and 2002 (both $92 \mathrm{~mm}$ less), the rainfall seems to have been well timed for the pea crop as yields were normal. The three warmest years in the time series were $2006\left(1.8^{\circ} \mathrm{C}\right.$ above average $), 2002$ $\left(1.6^{\circ} \mathrm{C}\right)$ and $1988\left(1.5^{\circ} \mathrm{C}\right)$, but only in 1988 was this associated with poor yield, indicate that timing is an important aspect of heat stress.

The value of feed-grade grain legumes has been well demonstrated in national research as well as internationally (Thomke 1986, Ogle and Hakansson 1988). Faba bean, pea and blue lupin have all been tested for their suitability in rations for pigs and turkeys, in order to replace imported soybean meal and to make use of on-farm production of feed. Faba bean has shown good potential in pig feeds (Partanen et al. 2007) while pea appeared to be superior for turkeys (Palander et al. 2006).

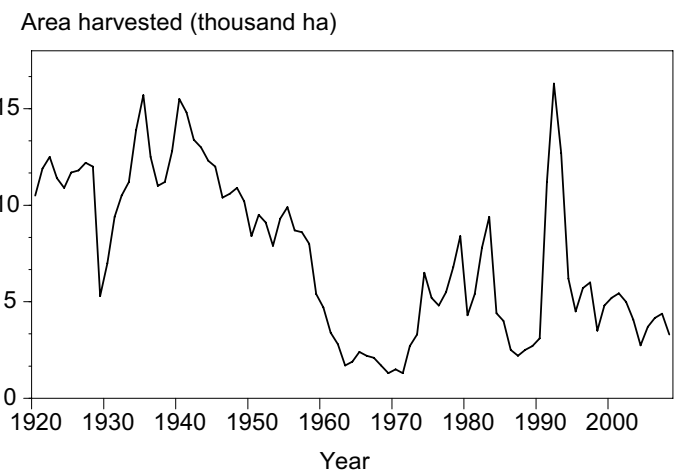

Fig. 1. Total area sown to grain legumes (pea and faba bean) in Finland from 1920 to 2008. Data from Suomen maatalouden historia II (Liitteet 6 ja 7) (1920-1950), Suomen tilastollinen vuosikirja 1953 (1951-1952), Maataloustilastollinen kuukausikatsaus 1953-1964, Maatalouden vuositilasto 1965-1982, Maatilatilastollinen vuosikirja 1983-2006, and TIKE Tiedote (2007 and 2008).

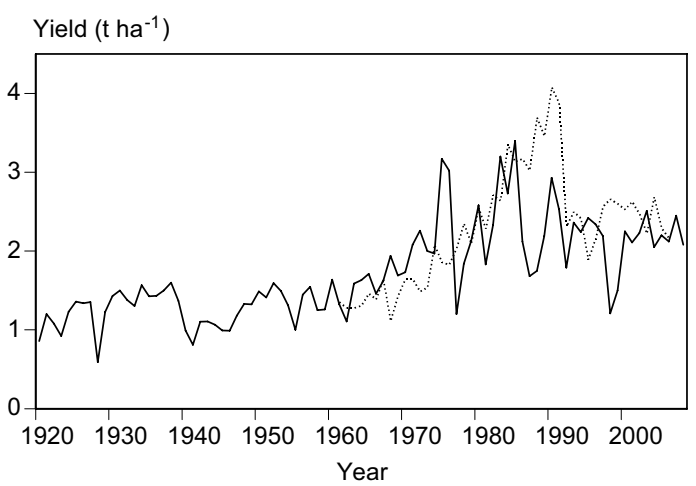

Fig. 2. Average yield of grain legumes (pea and faba bean) in Finland from 1920 to 2008. Sources as in Figure 1. Broken line shows EU average yields of pea from 1961 to 2008 (data from FAOstat, January 2009).

\section{Future prospects}

There is considerable potential to increase the area sown to grain legumes and to improve their yields in Finland. Imports of soybeans (Glycine max (L.) Merr.), soybean meal and rapeseed (Brassica napus L.) meal have expanded, and have exceeded 300 thousand tonnes in four of the last eight years (Fig. 
Vol. 18 (2009): 191-205.

3). Replacing that mass with home-grown grain legumes at an average yield of just $2 \mathrm{tha}^{-1}$ would require 150 thousand hectares, or a little less than one tenth of the arable area of the country. From Denmark to Spain, it has been shown that grain legumes can be included in profitable crop rotations every 3-6 years (Nemecek et al. 2008) and similar levels of legume use could apply in much of this country. Such an increase will allow farmers to take advantage of the numerous benefits of legumes in the crop rotation, including biologically fixed $\mathrm{N}$, improved soil structure and disrupted cereal disease cycles, while the national economy benefits from usage of home-grown instead of imported stock feeds. Mixed leys incorporating forage legumes, with limited fertilizer input $\left(50 \mathrm{~kg} \mathrm{~N} \mathrm{ha}^{-1}\right)$, produce the same yields as grass monoculture leys with heavy use of fertilizers (over $200 \mathrm{~kg} \mathrm{~N} \mathrm{ha}^{-1}$ ) and provide even better livestock productivity (Nykänen, unpublished results). A major increase in grain and forage legume crop area would both repay and demand increased investment in legume breeding, agronomy and pathology within the country and the Nordic region.

Continuing international progress in grain legume quality will contribute to the benefits of grain legume incorporation in animal diets. Faba beans low in tannin, vicine and convicine are already available (cv. Disco in France, released 2003) and

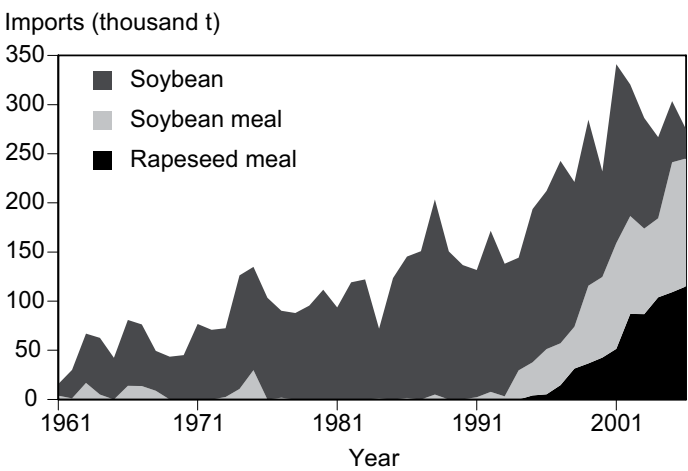

Fig. 3. Imports of protein-rich animal feed supplements to Finland from 1961 to 2006, divided into soybean (whole), oil-free soybean meal, and oil-free rapeseed meal. Data from FAOstat (January 2009). as they lack the usual limiting levels of the biologically active compounds, are suitable for incorporation into poultry and pig feeds at higher levels than has previously been possible (Duc et al., 2004). Peas with a low content of trypsin inhibitor and of tannin are similarly available for use in stockfeed. These valuable quality attributes need to be crossed into germplasm adapted to the boreal zone for use in Finland and the other Nordic and Baltic countries. The low starch and oil content of lupin seed and its high content of slowly digestible carbohydrate make it an excellent protein supplement for ruminants, as it is used in Australia, and some blue lupin cultivars can mature in southern Finland (Stoddard, unpublished results). For spring-sown grain legumes, earliness is a vital trait and the incorporation of novel sources of earliness genes will help ensure the harvestability and yield of the crop.

Expansion of the area of legume crops will also expand the area available to their pests and diseases. The spread of pea moth (Cydia nigricana Fabr.) is dependent on the proximity of pea fields (Huusela-Veistola and Jauhiainen 2006). Pea cultivars and breeding lines vary in their response to Aphanomyces euteiches Drechsl. root rot in Finnish soils, so there are prospects for breeding improved cultivars (Engqvist and Ahvenniemi 1997). Chocolate spot disease, caused by Botrytis fabae Sard. and B. cinerea Pers., is a major limitation to faba bean cropping in the country (Roukola and Vestberg 1978), and resistant cultivars are available elsewhere. Resistance breeding to major clover diseases will also become more important.

In their seach for rhizobia adapted to cold climate, Lipsanen and Lindström (1986) found that red clover rhizobia from the north were better adapted to a simulated cold climate than strains from southern Finland. Of the forage legumes studied in the Academy of Finland programme in the early 1980s (Varis and Sundman 1983), the nitrogen fixation of red clover and fodder galega seemed well adapted to our conditions, whereas that of lucerne was sensitive to cold (Lindström 1984b).

Current models of climate change suggest that the Finnish climate will become significantly warmer, with a greater chance of soil waterlogging 
Stoddard F.L. et al. Legumes in Finnish agriculture

in the winter and longer summer droughts. Abiotic stress resistance will be an important breeding objective, but by the same token, the milder climate may make more of the arable zone of the country suitable for grain legumes.

\section{References}

Abberton, M.T. \& Marshall, A.H. 2005. Progress in breeding perennial clovers for temperate agriculture. Journal of Agricultural Science, Cambridge 143: 117-135.

Bertilsson, J. Dewhurst, R. J. \& Tuori, M. 2001. Effects of legume silages on feed intake, milk production and nitrogen efficiency. In: Legume Silages for Animal Production. Special issue. Eds. R.J. Wilkins \& C. Paul, p. 39-45. FAL, Braunschweig, Germany.

Dewhurst, R.J., Merry, R., Bertilsson, J. \& Tuori. M. 2001. Effects of silages on diet digestibility and rumen function. In: Legume Silages for Animal Production. Special issue. R.J. Wilkins \& C. Paul (eds.), p. 47-53. FAL, Braunschweig, Germany.

Duc, G., Crépon, B., Marget, P. \& Muel, F. 2004. Fevita: a common name for a new type of faba bean. In: 5 th European Conference on Grain Legumes and ICLGG 2004, 7-11 June 2004, Dijon, France. AEP (ed.), p. 403. Associations Européenne des Protéagineux, Paris, France.

Elfving, F. 1896. Tärkeimmät viljelykasvit. Söderström, Helsinki, Finland. $232 \mathrm{pp}$ (In Finnish).

Engqvist, L.G. \& Ahvenniemi, P. 1997. Interactions between common root rot (Aphanomyces euteiches) and peas (Pisum sativum) in Finland. Acta Agriculturae Scandinavica, Sect. B., Soil and Plant Science 47: 242-247.

FAOstat. 2009. Faostat.fao.org., available on the internet, cited 30 January 2009. Food and Agricultural Organization of the United Nations.

Finnish Meteorological Institute. 2009. Finland's climate. Cited 15 June 2009. Available on the internet: http:// www.fmi.fi/weather/climate.html.

Grotenfelt, G. 1922. Suomalainen peltokasviviljelys. IV. Eri peltokasvien viljelys. Otava, Helsinki. 517 p. (In Finnish).

Hakala, K. \& Jauhiainen, L. 2007. Yield and nitrogen concentration of above- and below-ground biomasses of red clover cultivars in pure stands and in mixtures with three grass species in northern Europe. Grass and Forage Science 62: 312-321.

Halling, M.A., Hopkins, A., Nissinen, O., Paul, C., Tuori, M. \& Soelter, U. 2002. Nutritive quality of forage legumes grown in northern Europe. In: Multi-function grasslands: quality forages, animal products and landscapes. Proceedings of the 19th General Meeting of the European Grassland Federation, La Rochelle, France, 27-30 May 2002. J.-L. Durand, J.-C. Emile, C. Huyghe \& G. Lemaire (eds.), p. 126-127. British Grassland Society, Reading, UK.

Haynes, R.J. 1980. Competitive aspects of the grass-leg- ume association. Advances in Agronomy 33: 227-261.

Heikinheimo, A. 1946. Tuloksia vertailevista lajikekokeista Tammistossa 1938-45. Hankkijan Kasvinjalostuslaitos, Siemenjulkaisu 1946, p. 79-103. (In Finnish).

Heikinheimo, A. 1950. Tammiston alsikeapila. Hankkijan Kasvinjalostuslaitos, Siemenjulkaisu 1950, p. 128-130. (In Finnish).

Heikkilä, T., Toivonen, V. \& Mela, T. 1992. Comparison of red clover-grass silage with grass silage for milk production. In: Proceedings of the 14th General Meeting of the European Grassland Federation. Lahti, Finland, June 8-11, 1992. p. 388-391.

Helenius, J. \& Jokinen, K. 1994. Yield advantage and competition in intercropped oats (Avena sativa L.) and faba bean (Vicia faba L.): application of the hyperbolic yielddensity model. Field Crops Research 37: 85-94.

Hides, D. \& Humphries, M. 2000. Plant breeding from WPBS to IGER. IGER Innovations 4: 5-13.

Hovinen, S. \& Kivi, E. I. 1975 Valkuais- ja öljykasvit. Hankkijan Kasvinjalostuslaitos, Siemenjulkaisu 1975, p. 6066. (In Finnish).

Hovinen, S. 1982. Hankkijan Mikko härkäpapu. Hankkijan Kasvinjalostuslaitos tiedote 7: 1-20. (In Finnish).

Hovinen, S. 1984. Hankkijan Ukko-härkäpapu. Hankkijan Kasvinjalostuslaitos tiedote 14: 1-12. (In Finnish).

Hovinen, S. 1988. Breeding of field bean (Vicia faba L.) with early maturity. Journal of Agricultural Science in Finland 60: 261-267.

Hovinen, S. 1990. Palkoviljat. Hankkijan Kasvinjalostuslaitos, Siemenjulkaisu 1990,. p. 52-60. (In Finnish).

Howarth, R.E. 1975. A review of bloat in cattle. Canadian Veterinary Journal 16: 281-294.

Huokuna, E., Järvi, A. Rinne, K. \& Talvitie, H. 1985. Nurmipalkokasvit puhtaana kasvustona ja heinäseoksena. Maatalouden Tutkimuskeskus Tiedote 22/85: 1-12. (In Finnish).

Huurre, M. 2003. Maatalouden alku Suomessa. Esihistoriasta keskiajan loppuun. In: Suomen maatalouden historia I. Perinteisen maatalouden aika esihistoriasta 1870-luvulle. V. Rasila, E. Jutikkala \& A. Mäkelä-Alitalo (eds.). p. 38-66. Suomalaisen Kirjallisuuden Seura, Helsinki, Finland (In Finnish).

Huusela-Veistola, E. \& Jauhiainen, L. 2006. Expansion of pea cropping increases the risk of pea moth (Cydia nigricana; Lep., Tortricidae) infestation. Journal of Applied Entomology 130: 142-149.

Kajaste, S. 1990. Puna-apila. Hankkijan Kasvinjalostuslaitos, Siemenjulkaisu 1990. p. 73-74. (In Finnish).

Kallela, K. 1974. Estrogenic and anti-estrogenic characteristics of common Finnish fodders. Nordisk Veterinärmedicin 26: 97-107.

Känkänen, H., Kangas, A., Mela, T., Nikunen, U., Tuuri, H., Vuorinen,M. 1998. Timing incorporation of different green manure crops to minimize the risk of nitrogen leaching. Agricultural and Food Science in Finland 7: 553-567.

Karjalainen, R. \& Kortet, S.1987. Environmental and genetic variation in protein content of peas under northern growing conditions and breeding implications. Journal of the Scientific Agricultural Society of Finland 59: 1-9.

Karström, H. \& Virtanen, A.I. 1937. Über die Methoden zur Untersuchung und Beurteilung des A.I.V.-Futters bzw. anderer Silofutter. Annales Academiae Scientiarum Fen- 
Vol. 18 (2009): 191-205.

nicae Sarja A 48 (14). Laboratorium der Butterexportgenossenschaft Valio m.b.H. 23 p. (In German).

Kivi, E. I. 1955. Kalleherne. Hankkijan Kasvinjalostuslaitos, Siemenjulkaisu 1955. p. 119-122. (In Finnish).

Kivi, E. I. 1975. Villeherne. Hankkijan Kasvinjalostuslaitos, Siemenjulkaisu 1975. p. 159-160. (In Finnish)

Kuusela, E. 2004. Annual and seasonal changes in production and composition of grazed clover-grass mixtures in organic farming. Agricultural and Food Science 13: 309-325.

Kuusela, E. 2006. Annual and seasonal changes in mineral contents $(\mathrm{Ca}, \mathrm{Mg}, \mathrm{P}, \mathrm{K}$ and $\mathrm{Na}$ ) of grazed clovergrass mixtures in organic farming. Agricultural and Food Science 15: 23-34.

Laitinen, A. 1980. Puna-apila. Hankkijan Kasvinjalostuslaitos, Siemenjulkaisu 1980. p. 82-84. (In Finnish).

Leaver, J.D. 1985. Milk production from grazed temperate grassland. Journal of Dairy Research 52: 313-344.

Lee, M.R.F., Connelly, P.L., Tweed, J.K.S., Dewhurst, R.J., Merry, R.J. \& Scollan, N.D. 2006. Effects of high-sugar ryegrass silage and mixtures with red clover silage on ruminant digestion. 2. Lipids. Journal of Animal Science 11: 3061-3070.

Lindström, K. 1984a. Effect of various Rhizobium trifolii strains on nitrogenase $\left(\mathrm{C}_{2} \mathrm{H}_{2}\right)$ activity profiles of red clover (Trifolium pratense). Plant and Soil 80: 79-89.

Lindström, K. 1984b. Analysis of factors affecting in situ nitrogenase $\left(\mathrm{C}_{2} \mathrm{H}_{2}\right)$ activity of Galega orientalis, Trifolium pratense and Medicago sativa in temperate conditions. Plant and Soil 79: 329-341.

Lindström, K., Sarsa, M.L., Polkunen, J. and Kansanen, P. 1985. Symbiotic nitrogen fixation of Rhizobium (Galega) in acid soils, and its survival in soil under acid and cold stress. Plant and Soil 87: 293-302.

Lindström, K. and Myllyniemi, H. 1987. Sensitivity of red clover rhizobia to soil acidity factors in pure culture and in symbiosis. Plant and Soil 98: 353-362.

Lipsanen, P. and Lindström, K. 1986. Adaptation of red clover (Trifolium pratense) rhizobia to low temperatures. Plant and Soil 92: 55-62.

Loges, R., Kaske, A., Ingwersen, K. \& Taube, F. 2000. Yield, forage quality, residue nitrogen and nitrogen fixation of different forage legumes. In: The World Grows Organic, Proceedings of the 13th International IFOAM Scientific Conference, Basel, 28-31 August 2000. T. Alföldi, W. Lockeretz \& U. Niggli (eds.) p. 83. IFOAM, Bonn, Germany.

Marschner, H. 1995. Mineral nutrition of higher plants. London, UK: Academic Press. 889 pp.

Mela, T. 2003. Red clover grown in a mixture with grasses: yield, persistence and dynamics of quality characteristics. Agricultural and Food Science 12: 195-212.

Mela, T., Huokuna, E., Köylijärvi, J., Rinne, K., Simojoki, P. \& Teittinen, P. 1980. Comparison between Nordic red clover varieties in clover-grass mixtures. Annales Agriculturae Fenniae 19: 131-141.

Mulder, E.G., Lie, T.A. \& Houwers, A. 1977. The importance of legumes under temperate conditions. In: A Treatise on dinitrogen fixation. Section IV: Agronomy and Ecology. R.W.F. Hardy \& A.H. Gibson (eds.) p. 221-242. WileyInterscience, New York, USA.

Multamäki, K. \& Kaseva, A. 1987. Kotimaiset lajikkeet. Maatalouden Tutkimuskeskus, Tiedote 11/87. 8 p. (In
Finnish).

Mustonen, E., Tuori, M., Saastamoinen, I., Nykänen-Kurki, P., Isolahti, M., Saloniemi, H. \& Vanhatalo, A. 2006. Puna-apila lajikkeiden kasviestrogeenit. In: Maataloustieteen päivät 2006. A. Hopponen (ed.) Cited January 2009. Available on the internet:https://portal.mtt.fi/portal/page/ portal/AGRONET/HTML/NURMIYHDISTYS/sisallysluettelot/mustonen.pdf. (In Finnish).

Nemecek, T., Richthofen, J.S. von, Dubois, G., Casta, P., Charles, R., \& Pahl, H. 2008. Environmental impact of introducing grain legumes into European crop rotations. European Journal of Agronomy 28: 380-393.

Niemi, J. \& Ahlstedt, J. (eds) 2008. Finnish Agriculture and Rural Industries 2008. Agrifood Research Finland Economic Research Publication 108a. 96 p.

Nissinen, O. \& Raininko, K. 1975. Puna-apila. Hankkijan Kasvinjalostuslaitos, Siemenjulkaisu 1975. p. 96-99. (In Finnish).

Nykänen, A. 2008. Nitrogen dynamics of organic farming in a crop rotation based on red clover (Trifolium pratense) leys. Agrifood Research Reports 121: $60 \mathrm{p}$.

Nykänen, A., Granstedt, A., Laine, A. \& Kunttu, S. 2000. Yields and clover contents of leys of different ages in organic farming in Finland. Biological Agriculture \& Horticulture 18: 55-66.

Nykänen, A., Jauhiainen, L., Kemppainen \& Lindström, K. 2008a. Field-scale spatial variation in soil nutrients and in yields and nitrogen fixation of clover-grass leys. Agricultural and Food Science 17: 376-393.

Nykänen, A., Granstedt, A., Laine, A. \& Jauhiainen, L. 2008b. Residual effect of clover-rich leys on soil nitrogen and successive grain crops. Agricultural and Food Science 17: 73-87.

Nykänen-Kurki, P. \& Hakkola, H. 1994. Effect of red clover and nitrogen fertilization on forage quality at various growing times of the first and the second cut. In: Proceedings of the 3rd Congress of European Society for Agronomy, Abano-Padova, Italy. ESA (ed.) p. 614-615. European Society for Agronomy, Colmar Cedex, France.

Ogle, R.B. \& Hakansson, J. 1988. Nordic research with peas for pigs. Pig News and Information 9: 149-155.

Paatela, J. 1953. Eri-ikäisten peltonurmien osuudesta, käytöstä, pintalannoituksesta ja heinäsadosta Suomessa. Acta Agriculturae Fenniae 79: 1-60 (In Finnish).

Palander, S., Laurinen, P., Perttilä, S., Valaja, J. \& Partanen, K. 2006. Protein and amino acid digestibility and metabolizable energy value of pea (Pisum sativum), faba bean (Vicia faba) and lupin (Lupinus angustifolius) seeds for turkeys of different age. Animal Feed Science and Technology 127: 89-100.

Partanen, K., Siljander-Rasi, H., Honkavaara, M. \& Ruusunen, M. 2007. Effect of finishing diet and pre-slaughter fasting time on meat quality in crossbred pigs. Agricultural and Food Science 16: 247-258.

Pesola, V.A. 1942. Ilo ja Paula, uusia ruokahernelajikkeita. Valtion maatalouskoetoiminnan tiedonantoja 185. 12 p. (In Finnish).

Pesola, V.A. 1948. Maatalouskoelaitoksen kasvinjalostusosasto 25-vuotias. Koetoiminta ja Käytantö 3. 4 p.

Pitkänen, A-M. \& Huokuna, E. 1985. Fluctuation of reserve carbohydrates in tetraploid 'Tepa' red clover. Annales Agriculturae Fenniae 24: 71-75. 


\section{Stoddard F.L. et al. Legumes in Finnish agriculture}

Poutala, R.T. \& Hannukkala, A. 1995. The effect of the method of incorporation of Trifolium resupinatum $\mathrm{L}$. and Vicia villosa Roth. residues in the soil on the performance of a succeeding cereal crop. Acta Agriculturae Scandinavica 45: 251-257.

Pursiainen, P. \& Tuori, M. 2008. Effect of ensiling field bean, field pea and common vetch in different proportions with whole-crop wheat using formic acid or an inoculant on fermentation characteristics. Grass and Forage Science 63: 60-78.

Raatikainen, M. \& Raatikainen, T. 1975. Heinänurmien sato, kasvilajikoostumus ja sen muutokset. Annales Agriculturae Fenniae 14: 61-191 (In Finnish).

Ravantti, S. 1960. Puna-apila. Hankkijan Kasvinjalostuslaitos, Siemenjulkaisu 1960. p. 130-144. (In Finnish).

Ravantti, S. 1961. Suomalaisesta puna-apilasta. Maatalous ja koetoiminta 15: 174-183. (In Finnish).

Ravantti, S. 1965. Sinimailanen. Hankkijan Kasvinjalostuslaitos, Siemenjulkaisu 1965. p. 148-152. (In Finnish).

Relander, L.K. 1916. Tulokset herneen kylvöaika- ja kylvömääräkokeista Maanviljelystaloudellisen koelaitoksen kasviviljelysosastolla vuosina 1914-1915. Suomen maanviljelys-taloudellinen koelaitos. Tiedonantoja maamiehille 44. 5 p. (In Finnish).

Rinne, M. \& Nykänen, A. 2000. Timing of primary growth harvest affects the yield and nutritive value of timothyred clover mixtures. Agricultural and Food Science in Finland 2: 121-134.

Roukola, A.-L.\& Vestberg, M. 1978. Fungus diseases of field bean in Finland during 1975-1977. Journal of the Scientific Agricultural Society of Finland 50: 455-467.

Saastamoinen, M. 1992. Sohvi-herne. Maatalouden Tutkimuskeskus Tiedote 8/92. 41 p. (In Finnish).

Saastamoinen, M. 1995. Sunna-herne. Boreal Tiedote 5 / 1995. 12 p. (In Finnish).

Salonen, M \& Hiivola, S-L. 1963. Typpilannoituksen vaikutus puna-apilan ja nurminadan sadon määrään ja laatuun. (The effect of nitrogen fertilization on the yield and quality of the crop of red clover and meadow fescue). Annales Agriculturae Fenniae 2: 136-152. (In Finnish with English summary)

Sauli, J.O. 1916. Keskusosuusliike Hankkijan r.l. kasvijalostus- ja koeaseman toimintakertomus vuodelta 1915. Keskusosuusliike Hankkija r.l. Siemenjulkaisu. 1916. p. 29-47. (In Finnish).

Sauli, J.O. 1921. Vertailevat kokeet Tammistossa. Keskusosuusliike Hankkija r.l. Siemenjulkaisu 1921. p. 27-70. (In Finnish).

Sauli, J.O. 1925. Laatuselitys kauppaan lasketuista Tammiston jalosteista. Siemenjulkaisu. Keskusosuusliike Hankkija r.l. 1925. p. 110-114. (In Finnish).

Soininen, A.M. 1974. Vanha maataloutemme. Maatalous ja maatalousväestö Suomessa perinnäisen maatalouden loppukaudella 1720-luvulta 1870-luvulle. Journal of the Scientific Agricultural Society of Finland 46. Supplement: 1-459. (Published also as: Historiallisia tutkimuksia 96, Suomen historiallinen seura. (In Finnish).

Spatz, G. \& Benz, J. 2001. Two ecological controls of nitrogen fixation in white clover (Trifolium repens). Grassland Science in Europe 6: 11-13.

Steinshamn, H., Thuen, E. \& Brenoe, U.T. 2007. Clover species in grass-clover silages affects milk fatty acid composition. Journal of Animal and Feed Sciences 16. Sup- plement 1: 65-69.

Steinshamn, H. \& Thuen, E. 2008. White or red clovergrass silage inorganic dairy milk production: Grassland productivity and milk production responses with different levels of concentrate. Livestock Science 119: 202-215.

Teittinen, P. 1965. Puna-apilan esikasviarvosta (The value of red clover as a preceding crop). Acta Agriculturae Fenniae. 107: 175-190. (In Finnish, abstract in English)

Thomke, S. 1986. Swedish experiments on energy density in pig diets and with domestically grown protein feedstuffs - a review. World Review of Animal Production 22: 89-95.

Väisänen, J. 2000. Biological nitrogen fixation in organic and conventional grass-clover swards and a model for its estimation. Licentiate's thesis. University of Helsinki. Department of Plant Production. 42 p.

Valle, O. 1929. Nurmikasvit. In: Sauli, J.O. (ed.). Maa ja Metsä I, Kasvintuotanto II. WSOY, Porvoo. p. 747-798. (In Finnish).

Valle, O. 1935. Tuloksia vertailevista laatukokeista Tammistossa 1930-34. Hankkijan Kasvinjalostuslaitos Tammisto. p. 20-92. (In Finnish).

Valle, O. 1938. Tuloksia vertailevista laatukokeista Tammistossa 1935-37. Hankkijan Kasvinjalostuslaitos Tammisto. p. 53-106. (In Finnish).

Vanhatalo, A., Gäddnäs, T. \& Heikkilä, T. 2006. Microbial protein synthesis, digestion and lactation responses of cows to grass or grass-red clover silage diet supplemented with barley or oats. Agricultural and Food Science 15: 252-267.

Vanhatalo, A., Kuoppala, K., Toivonen, V. \& Shingfield, K.J. 2007. Effects of forage species and stage of maturity on bovine milk fatty acid composition. European Journal of Lipid Science and Technology 109: 856-867.

Varis, E. 1986. Goat's rue (Galega orientalis Lam.), a potential pasture legume for temperate conditions. Journal of Agricultural Science in Finland 58: 83-101.

Varis, E. \& Sundman, V. 1983. Biologinen typensidonta peltokasvien viljelyssä. (Biological nitrogen fixation in cultivation of field crops). Suomen Akatemian sopimustutkimuksen no. 383 loppuraportti. Helsinki: Helsingin yliopiston monistuspalvelu. (in Finnish)

Vilkuna, A-M. 2003. Kruunun maatalous: Kuninkaankartanot. Valtiojohtoisen talouden aika. Kustaa Vaasasta isoon vihaan 1520-1720. In: Suomen maatalouden historia I. Perinteisen maatalouden aika esihistoriasta 1870-luvulle. V. Rasila, E. Jutikkala \& A. Mäkelä-Alitalo (eds). p. 246-268. Suomalaisen Kirjallisuuden Seura, Helsinki, Finland (In Finnish).

Virri, T.J. 1939. Herne-kauran viljelystä. Valtion maatalouskoetoiminnan tiedonantoja 164: 11. (In Finnish).

Virri, T. 1951. Herne-kauran viljelystä. Journal of the Scientific Agricultural Society of Finland 23: 222-230. (In Finnish).

Virtanen, A.I. 1933. Über die Stickstoffernährung der Pflanzen. Suomalaisen tiedeakatemian toimituksia Sarja A 36 27 p. Helsinki: Suomalainen tiedeakatemia. (In German with Finnish summary).

Virtanen, A.I. 1946. Palkokasvien typpitalous. Maatalous ja koetoiminta 1: 37-53. (In Finnish).

Virtanen, A.I. \& Nurmia, M. 1936. Studies on the winter hardiness of clover. I. Effect of cutting on the carbohydrate reserves in red clover roots. Journal of Agricultural Sci- 
Vol. 18 (2009): 191-205.

ence 26: 288-295.

Wilmi, J. 2003. Tuotantotekniikka ja ravinnonsaanti. Valtiojohtoisen talouden aika. Kustaa Vaasasta isoon vihaan 1520-1720. In: Suomen maatalouden historia I. Perinteisen maatalouden aika esihistoriasta 1870-luvulle. V. Rasila, E. Jutikkala \& A. Mäkelä-Alitalo (eds). p. 159-182. Suomalaisen Kirjallisuuden Seura, Helsinki,
Finland. (In Finnish).

Ylimäki, A. 1967. Root rot as a cause of red clover decline in leys in Finland. Annales Agriculturae Fenniae 6: 1-59.

Ylimäki, A. 1969. Clover rot as a cause of poor overwintering of clover in Finland. Journal of the Scientific Agricultural Society of Finland 41: 222-242.

\title{
SELOSTUS
}

\section{Palkokasvit osana suomalaista maataloutta: historia, nykytilanne ja tulevaisuuden mahdollisuudet}

\author{
Frederick L. Stoddard, Simo Hovinen, Markku Kontturi, Kristina Lindström ja Arja Nykänen
}

\author{
Helsingin yliopisto ja MTT
}

Palkokasvit ovat tärkeitä viljelykasveja maailmanlaajuisesti, koska ne sitovat typpeä suoraan ilmasta omaan ja seuraavien kasvien käyttöön, katkaisevat kasvitautikierteen jatkuvassa viljanviljelyssä ja mahdollistavat rehun ja ruoan tuotannon paikallisesti. Suomessa on viljelty hernettä ja härkäpapua jo 500 vuotta e.K.r. Niiden käyttö ruoan tuotannossa on nykyään vähäinen, koska tilalle on tullut viljelyoloihimme paremmin sopeutuneita kasvilajeja. Palkoviljojen viljely on keskittynyt eteläiseen Suomeen niiden vaatiman pitkän kasvuajan vuoksi, kun taas monivuotiset puna-, alsike- ja valkoapila kasvavat luonnostaan koko Suomessa ja niitä onkin käytetty laajalti laidun-, kuivaheinä- ja säilörehunurmissa. Jalostusohjelmien tuloksena palkokasveista, erityisesti herneestä ja puna-apilasta, tuotettiin 1900-luvulla useita oloihimme soveltuvia uusia lajikkeita. Vuonna 1945 A. I. Virtanen palkittiin Nobelin kemian palkinnolla hänen tekemästään työstä biologisen typensidonnan hyödyntämisen ja säilörehun säilöntämenetelmän tutkimuksessa ja kehittämisessä. Huomionarvoista on myös se, että viljelijät harjoittivat seosviljelyä jo 1800-luvun alussa, jolloin esimerkiksi kauraa käytettiin herneen tukikasvina. Seosviljelyä on kehitetty ja tutkittu paljon, jotta sitä voitaisiin hyödyntää enemmän ja saada esiin sen tuottamat muutkin hyödyt.

Suomen liityttyä Euroopan Unioniin vuonna 1995 on ulkomaisten kasvilajikkeiden saatavuus helpottunut ja käyttö lisääntynyt, mutta rehun laadun ja kasvien aikaisuuden yhteensovittaminen vaatii edelleen lisäpanostusta. Tällä hetkellä palkoviljoja viljellään alle yhden prosentin osuudella maamme viljelyalasta. Jos viljelyala saataisiin nostettua 9-10 prosenttiin, voitaisiin näillä kasveilla korvata ulkomailta tuotu rehuvalkuainen. Ilmaston muutos muuttaa myös palkokasveihin kohdistuvia stressitekijöitä, jolloin on tarpeen panostaa kasvien viljelyyn, fysiologiaan ja jalostukseen liittyvään tutkimus- ja kehittämistyöhön. Tällöin palkokasvien tuomia monia etuja pystytään hyödyntämään viljelykierroissa. 